\author{
Research Article
}

\title{
A COMPARATIVE CLINICAL STUDY TO EVALUATE THE EFFICACY OF NAYOPAYAM SYRUP AND VYAGHRYADI SYRUP IN THE MANAGEMENT OF TAMAKA SHWASA
}

\begin{tabular}{|c|c|}
\hline $\begin{array}{l}\text { Naseeba C }{ }^{*} \text {, Ji } \\
{ }^{*} \text { PG Scholar, }{ }^{2} \text { Ass } \\
\text { Karnataka, India. }\end{array}$ & $\begin{array}{l}\text { esh Chowta } 2 \\
\text { nt Professor, Dept. of Kaumarabhritya, Alva's Ayurveda Medical College, Moodbidri, }\end{array}$ \\
\hline Article info & ABSTRACT \\
\hline Article History: & Tamaka shwasa is a Pitta Sthana Samudbava Pranavaha srotovikara in which the \\
\hline Received: 02-12-2021 & aggravated Kapha and Vata doshas plays a major role in causing Sthanasamshraya in the \\
\hline $\begin{array}{l}\text { Revised: 23-12-2021 } \\
\text { Accented. 08-01-2022 }\end{array}$ & Pranavaha srotas, where Udrita kapha gets accumulated and causes obstruction to the \\
\hline KEYWORDS: & normal movement of Prana Vata, which ends up in Pratiloma Gati of Vata producing the \\
\hline $\begin{array}{l}\text { Tamaka shwasa, } \\
\text { Nayaopayam syrup, } \\
\text { Vyaghryadi syrup, } \\
\text { Bronchial asthma. }\end{array}$ & $\begin{array}{l}\text { asthma, where the inflammation of the airway is produced by broncho-constriction. The } \\
\text { peak incidence of bronchial asthma is seen in } 5 \text { to } 10 \text { years of age group. Its prevalence } \\
\text { range is } 4 \% \text { to } 32 \% \text { for } 6 \text { to } 7 \text { years old children. In childhood, there is } 2: 1 \text { male/female } \\
\text { preponderance but the sex ratio gets equalizes by age } 30 \text {. The prevalence of bronchial } \\
\text { asthma is increasing by age worldwide. Nayopayam Kashayam and Vyaghryadi Kashayam } \\
\text { having Vatakaphahara and Shawasahara property, mentioned in Arogya Raksha Kalpa } \\
\text { Drumam and Ashtanga Hrdayam respectively are the formulations taken for the study. }\end{array}$ \\
\hline
\end{tabular}

\section{INTRODUCTION}

Tamaka shwasa is a disease of Pranavaha Srotas were Vayu is vitiated and blocked by Kapha, moves upward instead of its normal flow to the Uras ${ }^{[1]}$. The vitiated Doshas effect Rasa dhatu, involves Pranavaha Srotas and produces the disease. It is characterized by Pratiloma vayu, Kasa, Ghurghuraka, Ateeva Teevra vegam chashwasam, Pranaprapidakam, Kaphanishteevana, Muhurmuhur Shwasa, Urah parshwapeedana and so on ${ }^{[3]}$. Though, it is a Yapya disease. However in individual of recent origin of disease, person of Pravarabala or both said to be Sadhya ${ }^{[4]}$.

Tamaka Shwasa is analogous to Bronchial Asthma in its characteristics. It is a chronic inflammatory disorder of the lower airway is characterized by bouts of dyspnea, as a results of temporary narrowing of the bronchi by bronchospasm, mucosal edema and thick secretions ${ }^{[5]}$. Origin of asthma in most of cases is from the very first 2 years of life.

\begin{tabular}{|l|l|}
\hline \multicolumn{3}{|c|}{ Access this article online } \\
\hline Quick Response Code & \begin{tabular}{l} 
https://doi.org/10.47070/ijapr.v10i1.2240 \\
\hline
\end{tabular} \\
\hline $\begin{array}{l}\text { Published by Mahadev Publications (Regd.) } \\
\text { publication licensed under a Creative } \\
\text { Commons Attribution-NonCommercial- } \\
\text { ShareAlike 4.0 International (CC BY-NC-SA 4.0) }\end{array}$ \\
\hline
\end{tabular}

In India, rough estimates indicate a prevalence of between $10 \%$ and $15 \%$ in 5-11 year old children ${ }^{[7]}$.

Many environmental risk factors have been associated with the manifestation of Asthma. Bronchial Asthma in children has a greater risk of suffering and disability to perform the day to day activities. Dust, mites, animal dander, perfumes and other noncompatible house variants play an important role in asthma in childhood. Air pollutants, cigarette, environmental chemical smoke, injudicious usage of antibiotics will trigger the healthy respiratory cycle. Endogenic and exogenic allergens make the disease more acute in children.

Asthma in school going children is very much alarming nowadays resulting in thousands of school absenteeism, poor nutrition, ignorance and repeated noticeable adverse reactions and drug resistance makes the children more miserable and fatigue. Those children in their later age may develop difficulties in the life pattern, thoracic deformities resulting in pigeon chest, decline in the lung function etc.

\section{OBJECTIVES OF THE STUDY}

- To evaluate the efficacy of Nayopayam syrup and Vyaghryadi syrup in the management of Tamaka Shwasa in children. 
- To evaluate the comparative effect of Nayopayam syrup and Vyaghryadi syrup in the management of the disease Tamaka Shwasa.

\section{MATERIALS AND METHODS}

\section{Source of Data}

Literary Source: All the classical Ayurvedic texts, Modern literatures and contemporary texts including the websites about the disease and treatment were reviewed and documented for the study.

Sample Source: Subjects attending OPD and IPD's of Alva's Ayurvedic Medical College \& Hospital and Alva's Health Centre, Moodbidri were selected.

Drug Source: Drugs required are collected and properly identified under the supervision of Dravya Guna experts and medicines are prepared according to classical references at Rasa Shastra Bhaishajyakalpana lab, Alva's Ayurveda Medical College.

\section{Method of Preparation of Syrup}

Raw drugs were properly identified and collected from Alva's pharmacy and local markets. For making Nayopayam syrup, Bala (10 part), Jeeraka (1 part) and Shunti (1 part) were taken which is properly cleaned in running water to remove dirt and later dried and made into coarse powder. For making Vyaghryadi syrup, Vyaghri (1 part), Shunti (1 part), Guduchi (1 part) were taken which is properly cleaned in running water to remove dirt and later dried and made into coarse powder.

For making Nayopayam Kashayam, all the needed drugs were mixed together and added 8 times water and boiled and reduced to $1 / 4^{\text {th }}$ to prepare Kashaya. For making Vyaghryadi Kashayam, all the needed drugs were mixed together and added 8 times water and boiled and reduced to $1 / 4^{\text {th }}$ to prepare Kashaya. While preparing Vyaghryadi Kashaya, coarse powder of Pippali was added as Prakshepaka dravya.

Both prepared Kashayam were sieved and collected in a vessel and heated. Double quantity of Sharkara was added to the Kashaya and heated till it attains one - two thread consistency[11]. The syrup prepared was kept for self-cooling to normal temperature. Later it was collected in $100 \mathrm{ml}$ bottles.

\section{Method of Collection of Data}

Study Design: Randomized comparative clinical study Selection of Patients and Sample Size: 40 children having diagnostic criteria of Tamaka Shwasa was randomly divided into two groups.

Group A (Trial Group): This group contains 20 children who was administered Nayopayam Syrup.

Group B (Trial group): This group contains 20 children who was administered Vyaghryadi Syrup.

Diagnostic Criteria: Children were diagnosed based on the following features of Tamaka Shwasa as mentioned below:

- Shwasa (Difficulty in breathing)

- Kasa (Cough- dry or productive)

- Ghurghuraka (Wheeze/Ronchi)

- Kapha Nishteevana (Expectoration of sputum)

- Ateeva Teevra vegamcha Shwasam (Tachypnea)

- Muhur Muhur Shwasa (paroxysm of dyspnea)

- Nishtitante Kshanamsukhi (Relief of dyspnoea after expectoration)

- Aseenolabhatae Saukhyam (orthopnea)

- Urah Parshwa Peedana (Tightness of chest)

Inclusion Criteria

1) Children fulfilling 3-4 diagnostic criteria are included.

2) Children irrespective of sex, religion and socio economic status was taken.

3) Children between age group of 6-12 years.

4) Children with mild and moderate symptoms of Tamaka Shwasa.

\section{Exclusion Criteria}

1) Children with acute or severe exacerbation of asthma who requires immediate intervention were excluded.

2) Children suffering from other systemic disorders are excluded.

3) Children with history of malignancy, or any other congenital anatomical abnormalities of chest and Respiratory system.

\section{Table 1: Interventions}

\begin{tabular}{|l|l|l|c|}
\hline Groups & Drug & Dose & Duration \\
\hline Group A & Nayopayam syrup & $\begin{array}{l}5 \mathrm{ml}(6 \text { to } 9 \text { years }) \\
10 \mathrm{ml}(10 \text { to } 12 \text { years }) \text { TID }\end{array}$ & 1 month \\
\hline Group B & Vyaghryadi syrup & & 1 month \\
\hline
\end{tabular}

\section{Period of Observation}

- Treatment duration: 30 days.

- Assessment of children was done on before treatment, $15^{\text {th }}$ and $30^{\text {th }}$ day.

- Follow up period: Follow up study was done on $15^{\text {th }}$ day (45 4 th $\left.d a y\right)$ after completion of treatment.

- Total duration of study: 45 days. 
Table 2: Grading of Subjective and Objective criteria

\begin{tabular}{|c|c|c|c|c|}
\hline $\begin{array}{l}\text { Assessment } \\
\text { criteria }\end{array}$ & $\mathbf{0}$ & 1 & 2 & 3 \\
\hline \multicolumn{5}{|c|}{ Subjective Criteria } \\
\hline Shwasa & No dyspnea & $\begin{array}{l}\text { Dyspnea doesn't } \\
\text { hamper normal } \\
\text { activities }\end{array}$ & $\begin{array}{l}\text { Dyspnea hampering } \\
\text { daily/physical } \\
\text { activities }\end{array}$ & $\begin{array}{l}\text { Dyspnea forcing } \\
\text { absolute rest }\end{array}$ \\
\hline Kasa & No cough & $\begin{array}{l}\text { After ingestion of } \\
\text { irritable food }\end{array}$ & $\begin{array}{l}\text { During morning and } \\
\text { or night }\end{array}$ & $\begin{array}{l}\text { Frequently in day } \\
\text { and or night }\end{array}$ \\
\hline $\begin{array}{l}\text { Muhur Muhur } \\
\text { Shwasa }\end{array}$ & $\begin{array}{l}\text { No attacks of } \\
\text { dyspnea }\end{array}$ & $\begin{array}{l}\text { Episode of dyspnea } \\
\text { on exposure to } \\
\text { specific allergen/ } \\
\text { cold environment }\end{array}$ & $\begin{array}{l}\text { Less than } 2 \text { episodes } \\
\text { per month }\end{array}$ & $\begin{array}{l}\text { More than } 2-3 \\
\text { episodes per month }\end{array}$ \\
\hline $\begin{array}{l}\text { Aseenolabhatae } \\
\text { saukhyam }\end{array}$ & $\begin{array}{l}\text { Can lie flat \& } \\
\text { sleep } \\
\text { comfortably }\end{array}$ & $\begin{array}{l}\text { Can lie flat \& sleep } \\
\text { with little distress }\end{array}$ & $\begin{array}{l}\text { Can't lie flat \& has to } \\
\text { remain in semi } \\
\text { erect/upright position }\end{array}$ & $\begin{array}{l}\text { No comfort even in } \\
\text { sitting posture }\end{array}$ \\
\hline \multicolumn{5}{|c|}{ Objective Criteria } \\
\hline Ghurghuraka & No wheeze & At occasional spots & $\begin{array}{l}\text { Diffuse in one phase } \\
\text { of respiration }\end{array}$ & $\begin{array}{l}\text { Diffuse in both } \\
\text { phase of respiration }\end{array}$ \\
\hline $\begin{array}{l}\text { Ateeva } \\
\text { teevravegamcha } \\
\text { Shwasam }\end{array}$ & $\begin{array}{l}\text { RR } 18 \text { to } 23 \text { per } \\
\text { min }\end{array}$ & RR 24 to 30 per min & RR 31 to 40 per min & $\mathrm{RR}>40$ per min \\
\hline PEFR & Normal & $\begin{array}{l}>80 \% \text { of the } \\
\text { predicted }\end{array}$ & $\begin{array}{l}50-80 \% \text { of the } \\
\text { predicted }\end{array}$ & $\begin{array}{l}<50 \% \text { of the } \\
\text { predicted }\end{array}$ \\
\hline
\end{tabular}

Table 3: Assessment of severity of Asthma in children can done

\begin{tabular}{|c|c|c|c|}
\hline Based on & Mild & Moderate & Severe \\
\hline Frequency/ Month & $<$ one episode & $>$ One Episode & 4 Episodes \\
\hline Duration of Symptoms & Brief for hours & Prolonged 2-3 days & Almost continuous \\
\hline $\begin{array}{ll}\text { Activities } \\
\text { - } & \text { Eating } \\
\text { - } & \text { Sleep Disturbance } \\
\text { - } & \text { Playing } \\
\text { - } & \text { School Absenteeism }\end{array}$ & $\begin{array}{l}\text { Normal } \\
\text { Nil } \\
\text { Able } \\
\text { Nil }\end{array}$ & $\begin{array}{l}\text { Solids } \\
\text { At times } \\
\text { Restricted } \\
\text { Occasional }\end{array}$ & $\begin{array}{l}\text { Liquids } \\
\text { Frequent } \\
\text { Not able } \\
\text { Frequent }\end{array}$ \\
\hline Hospitalization & Rare & Occasional & Frequent \\
\hline PEFR & $60-80 \%$ predicted & $40-60 \%$ predicted & $40 \%$ \\
\hline
\end{tabular}

Table 4: Observations and interpretations

\begin{tabular}{|l|l|c|l|}
\hline Observations & Predominance & $\mathbf{\%}$ & Interpretations \\
\hline Age & 6 to 9 years & $55 \%$ & $\begin{array}{l}\text { Sample size is small which is not enough to shows the } \\
\text { prevalence of age in bronchial asthma. }\end{array}$ \\
\hline Gender & Male & $70 \%$ & $\begin{array}{l}\text { The sample size is small which is not enough to show the } \\
\text { prevalence of sex even though this study shows the data of } \\
2: 1 \text { ratio of males over females. }\end{array}$ \\
\hline Religion & Muslim & $55 \%$ & May be due to predominance of Muslims in the study area \\
\hline $\begin{array}{l}\text { Socio economic } \\
\text { status }\end{array}$ & Lower class & $55 \%$ & $\begin{array}{l}\text { May be due to low health care maintenance and partly due } \\
\text { to higher level of exposure to different kinds of allergens. }\end{array}$ \\
\hline Family history & Absent & $75 \%$ & $\begin{array}{l}\text { Apart from family history the other environmental factors } \\
\text { like dust, smoke, allergens, viral infections also plays a }\end{array}$ \\
\hline
\end{tabular}


Int. J. Ayur. Pharma Research, 2022;10(1):1-7

\begin{tabular}{|l|l|c|l|}
\hline & & & major role in developing asthma. \\
\hline Nature of diet & Mixed & $60 \%$ & $\begin{array}{l}\text { Guru guna of non-vegetarian food items leads to } \\
\text { Agnimandhya, Ama formation and Srotorodha which in fact } \\
\text { are the main factors for the development of Asthma. }\end{array}$ \\
\hline Sleep pattern & Disturbed & $70 \%$ & $\begin{array}{l}\text { The coldness of freeze foods aggravates both Vata and } \\
\text { Kapha. It leads to pooling of mucus in to the bronchial tree } \\
\text { causes aggravation of Asthma. }\end{array}$ \\
\hline Prakrthi & Vatakapha & $50 \%$ & $\begin{array}{l}\text { Nocturnal attack of asthma and cough may be the reason for } \\
\text { having disturbance in sleep }\end{array}$ \\
\hline $\begin{array}{l}\text { Habitat wise } \\
\text { distribution }\end{array}$ & Urban & $80 \%$ & $\begin{array}{l}\text { May be due to to the fact Tamaka Shwasa is Vata and } \\
\text { in urban area influence the increased incidence of Asthma } \\
\text { in children. }\end{array}$ \\
\hline Upashaya & $\begin{array}{l}\text { Intake of hot } \\
\text { substance }\end{array}$ & $100 \%$ & $\begin{array}{l}\text { In Tamaka Shwasa, Vata and Kapha are the main Doshas. } \\
\text { Both are having Sheeta property, hence Ushna is antagonist } \\
\text { of Sheeta, which suppress Vata and Kapha dosha. So the } \\
\text { subjects of Tamaka shwasa likes warm articles like tea, } \\
\text { coffee, hot water etc. }\end{array}$ \\
\hline
\end{tabular}

\section{RESULTS}

Table 5: Effect of Nayopayam syrup in subjective and objective parameter (Group A)

\begin{tabular}{|c|c|c|c|c|c|c|c|c|}
\hline Symptoms & BT & AT & BT-AT & $\%$ & $\begin{array}{l}\text { S.D } \\
( \pm)\end{array}$ & $\begin{array}{l}\text { S.E } \\
( \pm)\end{array}$ & WSRT Z Value & $P$ value \\
\hline Shwasa & 1.70 & 0.40 & 1.30 & 76.47 & 0.470 & 0.108 & 3.92 & $<0.05$ \\
\hline Kasa & 2.30 & 0.20 & 2.10 & 91.30 & 0.447 & 0.103 & 3.29 & $<0.05$ \\
\hline Muhur Muhur shwasa & 1.30 & 0.40 & 0.90 & 69.23 & 0.718 & 0.165 & 3.72 & $<0.05$ \\
\hline $\begin{array}{l}\text { Aseenolabhatae } \\
\text { Saukayam }\end{array}$ & 1.15 & 0.05 & 1.10 & 95.65 & 0.553 & 0.127 & 3.72 & $<0.05$ \\
\hline Ghurghuraka & 1.45 & 0.15 & 1.30 & 89.66 & 0.571 & 0.131 & 3.82 & $<0.05$ \\
\hline $\begin{array}{l}\text { Ateeva teevra Vegam } \\
\text { Cha Shwasam }\end{array}$ & 1.00 & 0.35 & 0.65 & 65.00 & 0.489 & 0.112 & 3.18 & $<0.05$ \\
\hline PEFR & 1.40 & 0.30 & 1.10 & 78.57 & 0.447 & 0.103 & 3.82 & $<0.05$ \\
\hline
\end{tabular}

Table 6: Effect of Vyaghryadi syrup in subjective and objective parameter (Group B)

\begin{tabular}{|l|c|c|c|c|c|c|c|c|}
\hline Symptoms & BT & AT & BT-AT & \% & S.D ( $\mathbf{\pm})$ & S.E ( $\mathbf{( )}$ & WSRT Z Value & P Value \\
\hline Shwasa & 1.70 & 0.65 & 1.05 & 61.76 & 0.605 & 0.139 & 3.62 & $<0.05$ \\
\hline Kasa & 1.90 & 0.80 & 1.10 & 57.89 & 0.912 & 0.209 & 3.82 & $<0.05$ \\
\hline Muhur muhur shwasa & 2.05 & 0.70 & 1.35 & 65.85 & 0.587 & 0.135 & 3.82 & $<0.05$ \\
\hline $\begin{array}{l}\text { Aseenolabhatae } \\
\text { Saukhyam }\end{array}$ & 1.50 & 0.15 & 1.35 & 90.00 & 0.489 & 0.112 & 3.92 & $<0.05$ \\
\hline $\begin{array}{l}\text { Ghurghuraka } \\
\text { Ateeva teevra Vegam } \\
\text { Cha Shwasam }\end{array}$ & 1.95 & 0.35 & 1.60 & 82.05 & 0.598 & 0.137 & 3.92 & $<0.05$ \\
\hline PEFR & 0.30 & 1.60 & 84.21 & 0.598 & 0.137 & 3.82 & $<0.05$ \\
\hline
\end{tabular}


Table: 7; Comparative effect of Group A and Group B

\begin{tabular}{|l|c|c|c|c|c|c|c|}
\hline $\begin{array}{l}\text { Signs and } \\
\text { Symptoms }\end{array}$ & $\begin{array}{c}\text { Group A } \\
\text { (Mean Score) }\end{array}$ & $\begin{array}{c}\text { Group B } \\
\text { (Mean Score) }\end{array}$ & $\begin{array}{c}\text { S.D } \\
\mathbf{( \pm )}\end{array}$ & $\begin{array}{c}\text { S.E } \\
\mathbf{( \pm )}\end{array}$ & $\begin{array}{c}\text { MW U } \\
\text { Value }\end{array}$ & $\begin{array}{c}\text { MW Z } \\
\text { Score }\end{array}$ & $\begin{array}{c}\text { P } \\
\text { Value }\end{array}$ \\
\hline Shwasa & 0.95 & 1.11 & 0.565 & 0.130 & 155 & 1.20 & $>0.05$ \\
\hline Kasa & 1.25 & 1.24 & 0.582 & 0.134 & 181 & 0.48 & $>0.05$ \\
\hline Muhur Muhur Shwasa & 0.89 & 1.20 & 0.465 & 0.107 & 90 & 2.94 & $<0.05$ \\
\hline $\begin{array}{l}\text { Aseenolabhatae } \\
\text { Saukhyam }\end{array}$ & 0.53 & 0.76 & 0.401 & 0.092 & 118 & 2.20 & $<0.05$ \\
\hline Ghurghuraka & 0.74 & 1.05 & 0.479 & 0.110 & 99 & 2.71 & $<0.05$ \\
\hline $\begin{array}{l}\text { Ateeva Teevra Vegam } \\
\text { Cha Shwasam }\end{array}$ & 0.68 & 0.89 & 0.400 & 0.092 & 120 & 2.15 & $<0.05$ \\
\hline PEFR & 0.73 & 0.81 & 0.540 & 0.124 & 179 & 0.55 & $>0.05$ \\
\hline
\end{tabular}

Table 8: Overall Result in Percentage (Group A and Group B)

\begin{tabular}{|l|l|l|l|l|l|l|}
\hline Group A & Group B & Mean Difference & SE ( $\mathbf{( )}$ & MW U Value & MW Z Score & P value \\
\hline 82.94 & 76.60 & 6.34 & 4.56 & 146.5 & 1.43 & 0.152 \\
\hline
\end{tabular}

Comparative analysis of the overall effect of the treatments in both the groups was done by statistically with Mann Whitney test. The test shows that the treatment is statistically not significant in Group A when compared to Group B, except Muhur Muhur Shwasa, Aseenolabhatae saukhyam, Ghurghuraka and Ateeva Teevra vegam cha shwasam. In Group A, overall result is $82.94 \%$ and Group B overall result is $76.60 \%$.

Table 9: Overall Effect

\begin{tabular}{|l|l|c|c|}
\hline \multirow{2}{*}{ Class } & \multirow{2}{*}{ Grading } & \multicolumn{2}{|c|}{ No. of Subjects } \\
\cline { 3 - 4 } & & Group A & Group B \\
\hline $0 \%$ & No improvement & 0 & 0 \\
\hline $1-30 \%$ & Mild improvement & 0 & 0 \\
\hline $31-60 \%$ & Moderate improvement & 2 & 3 \\
\hline $61-99 \%$ & Marked improvement & 10 & 16 \\
\hline $100 \%$ & Complete Relief & 8 & 1 \\
\hline
\end{tabular}

\section{DISCUSSION ON RESULTS}

\section{Effect of Treatment on Shwasa}

Shwasa (breathlessness) is due to bronchoconstriction (Srotosanga) of the airway due to inflammatory causes like increased secretion of epithelial secretions and bronchial mucous gland. So by administration of medicine, there would have reduction and clearance in the obstruction to the passage of Prana vayu by clearing the vitiated Kapha which results in reduction in Prana Vilomata.

\section{Effect of Treatment in Kasa}

Kasa is an effort to expel the Kapha (Malaroopa) secreted in the Pranavaha srotas. So by administration of medicine, there would have been an action in liquefaction of the sputum and then only the diminishing of cough is possible.

\section{Effect of treatment in Muhur Muhur Shwasa}

To fulfill the demand of oxygen, the respiratory rate gets increased. The symptom produced due to the demand but the anatomical structures are inefficient due to the bronchospasm and inflammation. This is equivalent to the Paroxysm dyspnoea described in modern science. So on the administration of medicine helps to reduce inflammation and bronchospasm.

\section{Effect of Treatment in Aseenolabhatae Saukhyam}

In sleeping or supine position dyspnea will increase due to increase of airway hindrance at that particular position, because of narrowing airways. So this study helps to reduce the Srotosanga, which in turns helps to reduce the obstructed airways.

\section{Effect of treatment in Ghurghuraka}

Wheeze (Ghurghuraka) is produced by vibration in the wall of an airway on the point of closer due to contraction of smooth muscles. So administration of medicine helps for the Kapha Vilayana and thus in turns helps to reduce Sroto sanga.

\section{Effect of Treatment in Ateeva Teevra Vegam Cha} Shwasam

Tamaka Shwasa has been described as the disease with Vega (paroxysmal attacks). This means that during the attack, patients feel very much 
troublesome. Due to obstruction of Shwasa marga, less amount of Prana Vayu can enter the body. So this study shows reduction and clearance in the obstruction and thus allows easy passage of Prana Vayu.

\section{Effect of Treatment in PEFR}

This may be due to the Kapha Vilayana property of the drug and helps in the normal Gati of Vayu. It shows significant reduction in the airway obstruction.

\section{Probable Mode of Action of Nayopayam Syrup}

Nayopayam Kashayam is mentioned in Arogya Raksha Kalpa drumam. Bala, Jeeraka and Shunti are the three ingredients of Nayopayam Kashayam. Though they are in Kashaya form, to make it easily administrable and palatable, syrup preparations are adopted. It has Vata Kaphahara, Shwasahara property and also predominantly Katu rasa and Ushna veerya in nature, which in turns act against the disease Tamaka shwasa. Among the ingredients of Nayopayam kashayam, the two ingredients (Jeeraka and Shunti) are having the predominance of Katu rasa, Laghu guna, Ushna veerya, Madhura Vipaka and Vata Kaphahara property. Thus by combinational effect, this formulation helps to remove the obstruction made by Kapha in the Pranavaha srotas, thus leading to Samprapti Vighatana and relieves the symptoms of the disease Shwasa. Bala moola have anti-inflammatory, anti- asthmatic activity and good immunity boosting activity. Thus it helps to reduce the inflammation of airways (Shothahara) and also provide strength to Pranavaha Srotas and acts as immunomodulatory (Rasayana action) by enhancing the immunity. Bala contains the phytochemicals ephedrine, vasicine, vasicinol, and vasicinone which act as bronchodilators, helping to clear the airways and facilitate easy breathing. Jeeraka acts as anti-inflammatory, immunity boosting action, digestive stimulant and carminative in nature. It is Ushna Veerya in nature. It helps to eliminate the Kapha and clears the airway for comfortable breathing. Also the Deepana, Pachana action helps to digest the Ama and in turns helps to normalize the Agni. Shunti is anti-inflammatory, digestive in nature and also had expectorant activity. So it helps in the easy expectoration of Kapha which have accumulated in Pranavaha Srotas. Thus, it helps for clearing the Srotomarga obstructed by increased Kapha.

\section{Probable Mode of Action of Vyaghryadi Syrup}

Vyaghryadi Kashayam having Vatakaphahara and Shawasahara properties are mentioned in Ashtanga Hridayam, Jwara Chikitsa chapter. Though they are in Kashaya form, to make it easily administrable and palatable, syrup preparations are adopted. The ingredients of Vyaghryadi syrup are Vyaghri, Shunti and Guduchi. Vyaghri is having Tikta and Katu rasa, Laghu, Ruksha Ushna Guna, Vatakapha hara, Agni deepana, Pachana, Anulomana, Srotoshodana, anti- inflammatory as well as antiasthmatic property. Shunti has Guru, Snigdha guna, Madhura Vipaka, acts as Deepana and Pachana and Ama Nashaka property. Gudhuchi is mentioned as Pathya ahara in Charaka Samhita, Bhaishagya ratnavali and Yogaratnakara in Tamaka shwasa due to its Kashaya rasa, Laghu Snigdha guna, Ushna Veerya and Madhura Vipaka. It is Deepana, Rasayana and Balya. It also has anti-inflammatory and immune modulatory action. The Ama Nashaka property, acts on Agni and alleviate Ama. This would clear up Rasa Dhatu dushti and excessive production of Mala Kapha. These drugs act at the level of Agni in Samprapti Vighatana. The Srotoshodana property helps to clean the various channels of Pranavaha Srotas which leads to Anulomana Gati of Vata. In this way Srotoshodaka drugs helps in Samprapti Vighatana. Vata Kaphahara property, which helps in the Samprapti Vighatana at the level of Pratiloma Vata Dosha and removes obstruction of Pranavayu. These drugs provide strength to Pranavaha Srotas and acts as immunomodulatory (Rasayana action) by enhancing the immunity.

\section{CONCLUSION}

Children in the early stages of Bronchial asthma, with early approach and less severity responded well during the first/second week of the treatment. Wheeze, breathlessness, cough are the main symptoms and signs of Bronchial asthma was observed in almost all the children during the study. Few children had rhinorrhea, heaviness in the head, cough prior to the main symptoms of asthma. The average percentage of improvement in Group A with Nayopayam syrup is $82.94 \%$ and Group B with Vyaghryadi syrup is $76.60 \%$. Even though both Nayopayam syrup and Vyaghryadi syrup have Vata Kaphahara and Shwasahara property, Nayopayam syrup is more effective than Vyaghryadi syrup in the management of Tamaka Shwasa in children.

\section{REFERENCES}

1. Acharya Sushrutha, Sushrutha Samhita with Ayurveda Tatva Sandipika Hindi Commentary of Ambikadatt Shastri, published by Chaukambha Sanskrit Sansthana, Varanasi, Edition: Reprint, Nidana sthana 1/21, 2009, p. 5.

2. Agnivesha, Caraka Samhita with Vidyasthini Hindi Commentary of Pt. Kashinashastri and Dr. Gorakhanath chaturvedi, published by Chaukambha Bharati academy, Varanasi, Edition: Reprint, Chikitsa sthana 17/8, 2013, p. 509.

3. Agnivesha, Caraka Samhita with Ayurveda Dipika commentary of Chakrapanidatta, published by Rastriya Sanskrit Sansthana, Edition: Reprint, Chikitsa sthana 17/55-60, 2006, p. 533, 535. 
4. Agnivesha, Charaka Samhita with Ayurveda Dipika commentary of Chakrapanidatta, edited by Kasinath Shastri \& Gorakhanath Chaturvedi, published by Chaukambha Bharti Prakashan, Varanasi, Edition: Reprint, Chikitsa sthana 17/62, 2004, p 51.

5. Suraj Gupte, The short textbook of pediatrics published by Jaypee brother's medical publishers (p) Ltd, Edition: 11 th, 2009, p. 334.

6. International study of bronchial asthma and allergies in childhood (ISSAC) Worldwide variations in the prevalence of Bronchial Asthma symptoms, Euro Respir J; 1998; 12: 315-35.

7. http://www.who.int/mediacentre/factsheets/fs20 6/en/
8. Dr Lal Krishnan; Arogya Raksha kalpa Drumam published by Chaukambha Sanskrit Series Office Varanasi; Edition: Reprint, 3 ${ }^{\text {rd }}$, Shwasa Hidma prakaram, 2019, p. 40.

9. Acharya Vagbhata, Ashtanga Hridaya translated by Prof. K.R. Srikantha Murthy published by Chaukambha Orientalia, Edition: Reprint, Chikitsa sthana 1/61, 2012, p. 184

10. Parthasarathy A, IAP Textbook of Pediatrics, Jaypee Publications, $4^{\text {th }}$ Edition: Reprint, Volume 1, Chapter 12.13, 2009, Pg.596.

11. Acharya Yadhav ji Trikamji, Dravya Guna Vijnanam, Satyabhamabai Pandurang, Edition: $2^{\text {nd }}$, Uttarardha, Pradhama Paribhasha Khanda, Shloka. 56,2003 p. $40-41$.

\section{Cite this article as:}

Naseeba C, Jithesh Chowta. A Comparative Clinical Study to Evaluate the Efficacy of Nayopayam Syrup and Vyaghryadi Syrup in the Management of Tamaka Shwasa. International Journal of Ayurveda and Pharma Research. 2022;10(1):1-7. https://doi.org/10.47070/ijapr.v10i1.2240

Source of support: Nil, Conflict of interest: None Declared

*Address for correspondence Dr. Naseeba C

PG Scholar,

Dept. of Kaumarabhritya,

Alva's Ayurveda Medical College, Moodbidri, Karnataka, India.

$\mathrm{Ph}: 9567120952$

Email: drnaseebas@gmail.com

Disclaimer: IJAPR is solely owned by Mahadev Publications - dedicated to publish quality research, while every effort has been taken to verify the accuracy of the content published in our Journal. IJAPR cannot accept any responsibility or liability for the articles content which are published. The views expressed in articles by our contributing authors are not necessarily those of IJAPR editor or editorial board members. 